\title{
Sözlü Tarihin Eğitim Uygulamalarına Entegrasyonunda Bir Başarı Öyküsü: The Foxfire Projesi*
}

\section{A Success Story in Integration of Oral History to Educational Implementations: The Foxfire Project}

\begin{abstract}
İlker DERE** (D)
Received: 24 May 2018

Review Article

Accepted: 19 March 2019

ABSTRACT: Oral history is one of the data collection tools of history that is also used as a teaching and learning method in educational implementations. Oral history implementations are generally made within the scope of a project in education area. The most famous of these projects is The Foxfire Project, initiated by Eliot Wigginton, who began his career at the Rabun Gap-Nacoochee High School, Georgia, the USA where he graduated from Cornell University in 1966. This successful initiation has been continuing without interruption since 1966. The aim of this study is to show the success story of The Foxfire Project, the pioneer of school-based oral history projects, from beginning to the present. For this purpose, the method of document analysis was preferred in the study. At the end of the data analysis, some important findings have been figured out about The Foxfire Project. First, The Foxfire, which started as a school magazine in 1968, acquired a national and international scientific journal identity and reputation. Secondly, 12-volume series of books were published, most of which were edited by teacher Wigginton, in order to bring together the oral history studies of students. Third, the learning and teaching experiences developed within the project throughout the time have been transformed into a model called "The Foxfire Approach to Teaching and Learning Method". Finally, the project has been a source of inspiration for making of similar school-based projects and issuing of school magazines.
\end{abstract}

Keywords: oral history, social studies education, teaching history, local history, the foxfire project.

ÖZ: Tarih biliminin veri toplama araçlarından biri olan sözlü tarih, eğitim uygulamalarında bir öğrenme ve öğretme yöntemi olarak da kullanılmaktadır. Sözlü tarih çalışmaları, eğitim alanında genelde bir proje kapsamında yapılmaktadır. Yapılan bu projelerin en ünlüsü, Cornell Üniversitesi'nden 1966 yılında mezun olduktan sonra Amerika Birleşik Devletleri'nin Georgia Eyaleti'nde hizmet veren Rabun Gap-Nacoochee Lisesi'nde görev yapmaya başlayan Eliot Wigginton tarafından başlatılan The Foxfire Projesi'dir. Bu başarılı girişim, 1966'dan günümüze kadar ara verilmeksizin sürdürülmüştür. Bu çalışmanın amacı, okul temelli sözlü tarih projelerinin öncüsü olan The Foxfire Projesi'nin 1966'dan günümüze kadar uzanan başarı öyküsünü ortaya koymaktır. Bu amaçla çalışmada doküman incelemesi yöntemi tercih edilmiştir. Veri analizi sonucunda The Foxfire Projesi'yle ilgili bazı önemli bulgulara ulaşılmıştır. Birincisi, ilk defa 1968 yılında bir okul dergisi olarak başlayan The Foxfire, Amerika ve dünya çapında bilimsel bir dergi hüviyeti ve ünü kazanmıştır. İkincisi, öğrencilerin sözlü tarih çalışmalarını bir araya getiren ve büyük bölümü öğretmen Wigginton tarafindan düzenlenen 12 ciltlik kitap serisi yayımlanmıştır. Üçüncüsü, bu proje kapsamında zaman içinde geliştirilen öğrenme ve öğretme tecrübeleri, "The Foxfïre Öğrenme ve Öğretme Yaklaşımı” adıyla bir modele dönüştürülmüştür. Son olarak bu proje, Amerika'da birçok okulda benzer projelerin yapılmasına ve dergilerin çıkarılmasına ilham kaynağı olmuştur.

Anahtar kelimeler: sözlü tarih, sosyal bilgiler eğitimi, tarih öğretimi, yerel tarih, the foxfire projesi.

\footnotetext{
* Bu çalışma, 6. Uluslararası Sosyal Bilgiler Eğitimi Sempozyumu'nda 05.05.2017 tarihinde "Sözlü Tarihin Eğitim Uygulamalarına Entegrasyonunda Bir Başarı Öyküsü: The Foxfire Projesi" başlığıyla sözlü bildiri olarak sunulmuştur.

${ }_{* *}$ Asst. Prof. Dr., Necmettin Erbakan University, Konya, Turkey, idere@erbakan.edu.tr, https://orcid.org/0000-00030993-7812
}

Citation Information

Dere, İ. (2019). Sözlü tarihin eğitim uygulamalarına entegrasyonunda bir başarı öyküsü: The foxfire projesi. Kuramsal Eğitimbilim Dergisi [Journal of Theoretical Educational Science], 12(2), 511-531. 


\section{Giriş}

Sözlü tarih, insanların anılarının ve tanıklıklarının kaydedilerek yorumlanmasıdır. İnsanlar, sözlü tarih yoluyla olayları hatırlar ve kendilerine özgü bakış açılarıyla tanıklıklarını anlatırlar (Ritchie, 2015). Bu yöntem, başta tarih bilimi olmak üzere sosyoloji, gazetecilik, halk bilimi ve eğitim gibi birçok alanda bir veri toplama ya da öğrenme ve öğretme yöntemi olarak kullanılmaktadır (Abrams, 2010). Sözlü tarih terimi ilk defa isim babası New Yorklu bir hikâye anlatıcısı olan Joe Gould (Mitchell, 1996) tarafından kullanılmasına rağmen kurumsal kimliğini 1948 yılında Allan Nevins tarafından Kolombiya Üniversitesi’nde ilk Sözlü Tarih Ofisinin açılmasıyla kazanmıştır (Grele \& Terkel, 1985).

Sözlü tarih, Kolombiya Üniversitesi'nde Sözlü Tarih Ofisi’nin açılmasından sonra çeşitli disiplinler tarafından tanınmaya başlamıştır. Özellikle Nevins'ın araştırma ofisinde hâkimler, kabine üyeleri, senatörler, yayıncılar, işletme yöneticileri ve bazı sivil liderlerden oluşan kadınlar ve erkeklerle yaptığı görüşmeler (Shaughnessy, 1960), yöntemin yaygınlaşmasında önemli bir rol oynamıştır. Bu görüşmeler, sözlü tarih alanında "elit sözlü tarihçilik" olarak anılmıştır.

Kolombiya Üniversitesi'ndeki Allen Nevins'ın çabalarından sonra 1952 yılında William Owen Texas Tarih Merkezi'nde sözlü tarih çalışmalarına başlanmıştır. İzleyen yıllarda (1954’te), Kaliforniya Üniversitesi'nde (Berkeley) Bölgesel Sözlü Tarih Ofisi (Star, 1977) ve 1960 yılında ilk defa bir başkanlık Kütüphanesi'nde (Harry S. Truman Presidential Library and Museum) bir sözlü tarih programı açılmıştır (Ritchie, 2015). Özellikle 1970'ler ve 1980'lerde sözlü tarihin gelişmesinde ve popülerleşmesinde, Studs Terkel'ın 1958 yılında Amerika Birleşik Devletleri'nin Şikago (Chicago) kentinde yayın yapan WFMT isimli radyoda başlattığı programda; dönemin düşünürleri, yazarları, mimarları, politikacıları, müzisyenleri ve toplumun çeşitli kesimlerinden insanlarla yaptığı görüşmeler önemli rol oynamıştır (Gregson, 2009). Bu etki sayesinde Studs Terkel'1n Hard Times [Zor Zamanlar, 1970], Working [Çalışma, 1974] ve The Good War [İyi Savaş, 1984] adlı kitapları, Amerika'da en çok satılan kitaplar arasına girmiştir (Ritchie, 2015).

ABD’nin yanında sözlü tarihin gelişmesi ve yaygınlaşmasında önemli rol oynayan ülkelerden biri de İngiltere olmuştur. Burada sözlü tarih, daha çok hem halk bilimci hem de sözlü tarihçi olan George Ewart Evans'ın öncülüğünde gelişmiştir. Evans, Allan Nevins'ın aksine, kırsal alanlarda yaptığı sözlü tarih araştırmalarıyla sosyal tarih alanında önemli çalışmalar yürütmüştür. Onun en önemli eseri, "Ask the Fellows Who Cut the Hay [Otu Kimin Biçtiğini Arkadaşlara Sorun, 1956]" adlı kitabıdır. İngiltere'de sözlü tarihin önde gelen isimlerinden Paul Thompson'a göre bu eser; Evans'ın çalışmalarının temelini oluşturan, folklor anlayışı ve çalışma tecrübesini ve güçlü bir yerel tarih geleneğini yansıtan, başlı̆̆ 1 ve giriş metniyle İngiltere'deki sözlü tarih hareketinin başlangıcıdır (Thompson, 1999).

Evans'tan sonra İngiltere'de sözlü tarih denilince akla Paul Thompson gelmektedir. Thompson, hazırladığı doktora tezi kapsamında İngiltere'de 1872-1906 yılları arasında doğmuş 500 kişiyle iş ve günlük yaşamlarına dair sözlü tarih mülakatları yürütmüştür. "The Edwardians: the Remaking of British Society [Edward Dönemi İnsanları: Britanya Toplumunun Yeniden Oluşumu, 1975]” adını verdiği bu çalışması, 
İngiltere'deki sözlü tarih çalışmaları arasında kaynak kişi sayısının büyüklüğü açısından önemli bir yere sahiptir.

Kolombiya Üniversitesi'nde sözlü tarihin kurumsallaşmasından sonra çeşitli disiplinlerde kısa sürede gelişen sözlü tarih, eğitim uygulamalarına entegre edilerek üniversiteler başta olmak üzere birçok lise, ortaokul ve hatta ilkokul kademesinde bir öğretim yöntemi olarak kullanılmaya başlanmıştır (Caunce, 2001). Bu kapsamda sözlü tarih kursları; kütüphanelerde, gazetecilik bölümlerinde ve Amerikan çalışma programlarında (daha çok lisansüstü kademelerinde) okutulan sözlü tarihin teorisi ve metodolojisiyle ilgili derslerde ele alınmıştır (Ritchie, 2015). Nitekim 1974 yılında, Amerikan Sözlü Tarih Birliği (OHA) tarafından öğretmenlere yapılan anketlerde sözlü tarihin bütün okul seviyelerindeki kullanımının büyük bir artış gösterdiği ortaya çıkarılmıştır (Starr, 1977). Bu gelişmelere paralel olarak çeşitli eyaletlerde okul temelli sözlü tarih projeleri yapılmıştır. Bu projelerden bazıları, önce ulusal daha sonra uluslararası çapta ün kazanmıştır. Bu projelerin en ünlüsü, bu çalışmaya konu alan The Foxfire Projesi'dir. 1966 yılında bir okul dergisi olarak başlayan bu proje, kısa sürede uluslararası bir üne ulaşmıştır.

Türkiye'de ise sözlü tarihin eğitim uygulamalarına entegre edilmesine yönelik ilk girişimler, 1950'li yıllarda Çağatay Uluçay tarafından yapılmıştır (Safran \& Ata, 1998; Uluçay, 1958). Ancak bu çaba, münferit bir örnek olarak kalmıştır. 1990'lı yıllara kadar bazı sözlü tarih çalışmaları yapılsa da sözlü tarihin Türkiye'de asıl tanınırlık kazanmaya başlaması, 1990'lı yıllarda Tarih Vakfı'nın faaliyetleriyle mümkün olmuştur (Öztürkmen, 2002). Bu kapsamda Tarih Vakfı, "I. Sözlü Tarih Atölyesi” (Tunçay, 1993) adıyla Türkiye'deki ilk sözlü tarih atölyesini gerçekleştirmekle kalmamış, 11. Uluslararası Sözlü Tarih Konferansı'nın da İstanbul'da düzenlenmesine öncülük etmiştir. $\mathrm{Bu}$ gelişmelere rağmen eğitimde sözlü tarihin bir öğretim yöntemi olarak yaygınlaşmaya başlaması, 2005 yılından sonra mümkün olmuştur (Dere, 2018). 2005 yılından itibaren öğretim programlarının yapılandırmacı eğitim felsefesine göre düzenlenmesiyle sözlü tarih, Sosyal Bilgiler Öğretim Programında bir öğrenme ve öğretme yöntemi olarak yer almıştır (Millî Eğitim Bakanlığı [MEB], 2006). Bu gelişme, sözlü tarihin eğitim uygulamalarına entegrasyonu konusundaki çabaları artırmıştır. Bu kapsamda YÖK Ulusal Tez Merkezi incelendiğinde, Türkiye'de sözlü tarihle ilgili yapılmış (1995-2017 yılları arasında) 175 tez tespit edilmiştir (YÖK Ulusal Tez Merkezi, 2017). Bu tezler, sosyal bilgiler ve tarih eğitimi açısından sınıflandırıldığında; sosyal bilgiler eğitiminde 2 doktora (Dere, 2017; Sar1, 2007) ve 6 yüksek lisans (Kaya, 2013; Özer, 2012; Öztaşçı, 2017; Sar1, 2002; Temir, 2015) tezinin yapıldı̆̆1 görülmektedir. Tarih eğitiminde bir doktora (Arslan, 2012) ve altı yüksek lisans tezinin (Avc1-Akçalı, 2007; Durmuş, 2013; Işık, 2008; Kaplan, 2005; Kumru, 2009; Küpüç, 2014) hazırlandığı tespit edilmiştir. Bu tez çalışmaları, sözlü tarihin sosyal bilgiler ve tarih derslerinde kullanımı konusunda birikim oluşturulmasına önemli katkı sağlamıştır.

Türkiye'de akademik araştırmalarda sözlü tarihe gittikçe ilgi artmasına rağmen hem eğitim kurumlarında hem de sivil toplum kuruluşlarında yeterince sözlü tarih projelerinin geliştirilmediği ya da yapılmadığı görülmektedir. Bu tabloya rağmen bazı önemli kurum ya da kuruluşlar tarafından çeşitli sözlü tarih projeleri Bu tabloya rağmen bazı önemli kurum ya da kuruluşlar tarafından çeşitli sözlü tarih projeleri (Bilim ve Sanat Vakfı [BİSAV), 2018; İzmir Büyükşehir Belediyesi, 2013; Metin, 2007; Kafkas Vakfı, 2014; Tarih Vakfi, 2018) yürütülmüştür. Bu gelişmelerin yanında İbn Haldun 
Üniversitesi'nde Türkiye'nin ilk sözlü tarih uygulama ve araştırma merkezinin "Sözlü Tarih ve Toplumsal Hafiza Uygulama ve Araştırma Merkezi (SÖZMER)" adıyla kurulmuş olması, oldukça olumlu bir gelişmedir. Nitekim bu merkez, kurulduktan kısa bir süre sonra "Türkiye'de Din, Devlet, Toplum ve Hafiza 1923-1950" (İbn Haldun Üniversitesi, 2018) adlı bir proje başlatmıştır. Bu olumlu gelişmelere rağmen bu tür projelerin okullara taşınamadığ 1 ve okul temelli çalışmaların yeterince yapılamadığı görülmektedir. Bunu test etmek için yalnızca Google arama motoru, DergiPark, Google Akademik, Academia ve ResearchGate gibi akademik mecraları taramak yeterlidir.

Türkiye'deki mevcut durum göz önünde bulundurulduğunda, dünyada sözlü tarih geleneğinin en önemli iki kolundan biri olan Amerika Birleşik Devletleri'nde yapılan ve günümüze kadar sürdürülen The Foxfire Projesi'nin, Türkiye'deki okul temelli çalışmalara ilham olabilme potansiyeli olduğu kanaatine varılmıştır. Bu gerekçeyle ilgili projenin iyi bir örnek olarak Türkiye'de tanıtılmasına karar verilmiştir. Bu kapsamda bu çalışmanın amacı, okul temelli sözlü tarih projelerinin öncüsü olarak kabul edilen The Foxfire Projesi'nin 1966'dan günümüze kadar uzanan başarı öyküsünü ortaya koymak olarak belirlenmiştir. Bu amacı gerçekleştirmek için aşağıdaki araştırma sorularına cevap aranmıştır;

1) The Foxfire Projesi nasıl ortaya çıkmış ve gelişmiştir?

2) The Foxfire, ne tür başarılar kazanmıştır?

3) The Foxfire Projesi'nde sözlü tarih, eğitime nasıl entegre edilmiştir?

4) The Foxfire'ın eğitim uygulamalarına ve projelerine nasıl yansımıştır?

\section{Yöntem}

Çalışmada doküman incelemesi yöntemi kullanılmıştır. Bu yöntem, genel tarama veya içerik çözümlemesi olmak üzere iki amaç için kullanılmaktadır (Çepni, 2012). Bu araştırmada doküman incelemesi, genel tarama, yani alanyazının derinlemesine taranması ve incelenmesi amacıyla kullanılmıştır. Çünkü bu yöntemin analiz ve örneklem büyüklüğü gibi çeşitli avantajları bulunmaktadır (Yıldırım ve Şimşek, 2008). Yöntemin öngördüğü şekilde, The Foxfire Projesi'nin gelişim süreci, proje kapsamında yayımlanan eserler, projenin çıktıları ve eğitime yansımalarını içeren yazılı ve görsel materyaller incelenmiştir.

\section{Örneklem}

Araştırmanın örneklemini The Foxfire Dergisi, The Foxfire Projesi'nin kitapları, projeyle ilgili yazılmış makaleler, kitaplar, değerlendirme yazıları ve görsel materyaller oluşturmuştur. İncelenen çalışmalar, 1972-2016 yılları arasında ABD’de The Foxfire Projesi’yle ilgili kaynaklarla sınırlıdır.

\section{Veri Kaynakları}

Çalışmada veri toplamak için proje kapsamında yayımlanan 12 adet The Foxfire kitabı, The Foxfire Dergisi, proje hakkında yayımlanan kitaplar ve makaleler doküman incelemesiyle değerlendirilmiştir. Bu kapsamda öncelikle The Foxfire Projesi'nin kitapları ve The Foxfire Dergisi'nin bazı makaleleri okunmuş ve bazı notlar alınmıştır. Bunun yanında projeyi konu alan diğer kitaplar, makaleler ve kaynaklar taranmıştır. Bu işlemler neticesinde proje hakkındaki düşünceler ve yansımalar netleştirilmiştir. 


\section{Veri Analizi}

Çalışmada dokümanlardan elde edilen veriler, betimsel olarak analiz edilmiştir. $\mathrm{Bu}$ yöntem, genellikle araştırmanın kavramsal yapısı, temaları veya boyutlarının önceden açık bir biçimde belirlendiği araştırmalarda tercih edilir. Burada amaç, elde edilen verilerin öncelikle sistematik ve açık bir biçimde betimlenmesi, daha sonra ilgili betimlemelerin açıklanması, yorumlanması ve sonuçların sunulmasıdır (Çepni, 2012). $\mathrm{Bu}$ çerçevede betimsel analiz için önceden belirlenen tematik çerçeveye göre bulgular, tanımlanmış, açıklanmış ve yorumlanmıştır. Ayrıca analiz sırasında temel alınan araştırma soruları ya da konu başlıklarına uygun verilerden doğrudan alıntılar (Ekiz, 2007) kullanılmıştır. Bu analizler ve yorumlar neticesinde The Foxfire Projesi'nin eğitim uygulamaları için anlamı ortaya konulmuş ve Türkiye'de ileride yapılabilecek okul temelli projelere örnek olabileceği yönleri bulgular bölümünde vurgulanmıştır.

Son olarak çalışmanın temel veri kaynağı dokümanlar olduğu için güvenirlik ve geçerliliği sağlamak için Çepni (2012) tarafından önerilen bazı işlemler yapılmıştır. Bu kapsamda öncelikle ulaşılan kaynakların doğruluğu ve gerçekliği değerlendirilmiştir. Neticede ulaşılan kaynakların projeyle ilgili orijinal kaynaklar olduğu tespit edilmiştir. Ardından kullanılan kaynakların araştırma konusuyla ilgisi gözden geçirilmiş, ilgisiz kaynaklar elenmiştir. Ayrıca yorumlamanın doğru yapılıp yapılmadığını kontrol etmek için diğer araştırmacıların görüşlerine başvurulmuştur. Son olarak araştırmanın güvenirliliğini artırmak için veriler; açık ve anlaşılır bir şekilde sunulmuştur.

\section{Bulgular ve Yorum}

$\mathrm{Bu}$ bölümde araştırma sorularına ilişkin bulgulara yer verilmiştir. Bulgular; The Foxfire Projesi'nin Doğuşu ve Gelişim Süreci, Projenin Kazandığı Başarılar, Sözlü Tarihin Eğitim Uygulamalarına Entegrasyonu ve The Foxfire Projesi'nin Yansımaları şeklinde dört ana başlık altında toplanmıştır.

\section{The Foxfire Projesi'nin Doğuşu ve Gelişimi}

Sözlü tarih, bir araştırma disiplini olarak 20. yüzyılın ikinci çeyreğinde, 1930'ların sonunda, Federal Yazarlar Projesi'yle (Yetman, 2001) Amerika'da görünürlük kazanmaya başlamıştır. Ancak Allan Nevins'ın Kolombiya Üniversitesi'nde Sözlü Tarih Araştırma Ofisi'ni açarak ilk modern sözlü tarih arşivini oluşturmasıyla kurumsallaşmıştır. İlk zamanlar elit isimlerle yapılan bu çalışmalar, zamanla geniş halk tabakalarının hayatını ele alan projelere (sosyal tarih) evrilmiştir. Doğal olarak bu gelişmeler, okul temelli projelerin yapılmasına zemin hazırlamıştır. Bu projelerden birisi, Cornell Üniversitesi İngilizce bölümünden 1966 yılında mezun olan ve "Öğretim" alanında Master derecesine sahip olan Eliot Wigginton tarafından başlatılmıştır (McLellan, 1996). Amerika Birleşik Devletleri'nin Georgia Eyaleti'nde bulunan Apalaş Dağları'nın (Appalachians) hemen yanı başında hizmet veren 240 ögrencili Rabun Gap-Nacoochee Lisesi'nde başlatılan projeye "The Foxfire Projesi" ad1 verilmiştir. Öncü öğretmen Wigginton, 1966 yılında 9. ve 10. sınıf öğrencilerini okutmak için İngilizce ve Coğrafya öğretmeni olarak göreve başladığında okuldaki diğer öğretmenlerin öğrencilerden sürekli olarak şikâyetçi olduğunu ve onları 'umutsuz vakalar' olarak yaftaladıklarını gözlemlemiştir. Nitekim kendisi de öğretmenlerin şikâyetçi olduğu durumlara ilk zamanlar sıkça şahit olmuştur. Wigginton, okula gittiği ilk zamanlarda karşılaştığı öğrencilerini şu şekilde tasvir etmiştir: 
Yaklaşık 6 hafta sonra zarar tespiti yapmak için bir anket uyguladım. Sınıftaki kürsüm [öğretmen masas1], yani hiçbir öğrencinin kendilerini dinlemediği zamanlarda arkasına sinen öğretmenleri koruyan araç... Kürsüm ise, Tommy Green ders sırasında çakmağıyla onu yakmaya çalıştığı için kavrulmuştu. Bu arada Charles Henslee, döşeme tahtalarını kazırken bıçağının sapı kopmuştu. Her masa, grafitlerle doluydu. Benim sarı kutumdaki tebeşir çoktan bitmişti. Globe Theatre grafikleri, raptiyelerle desteklenmişti. 9 tane su tabancasına el koymuştum ama öğleden sonra burnumun dibinden yine kaybolmuştu. Derin bir nefes aldıktan sonra birkaç kâğıt uçak yaptım ve daha iyi koşullar için düşünmeye başladım. Ya buna razı ol ya da her şeye yeniden başla... Cevap belliydi. Ben bu yılı onurlu bir şekilde bitirirsem, otoritemi yeniden değerlendirmem gerekecek diye düşündüm. Böylece onların hiçbirisi, bana kabadayılık taslayamayacaktı (Wigginton, 1972, s. 9-10).

$\mathrm{Bu}$ düşüncelerle göreve başlayan Wigginton, öğrencilerini diğer öğretmenler gibi kendi hallerine bırakmaktansa ikinci seçeneği tercih etmiş ve "her şeye yeniden başla!"’ diyerek yola çıkmıştır. Bunu başarmak için öncelikle öğrencilere güvendiğini göstermeye çalışmıştır. Çünkü onlarla birlikte çalışma konusundaki diğer alternatiflerin yararsız olduğunu görmüştür. Bu düşünceyle bir gün sınıfına gitmiş ve onlara: "Ders kitaplarını bir kenara bırakıp dergi çıkarmaya ne dersiniz?” demiştir. Bu çağrıyı, öğrenciler olumlu karşılamış ve bu kıvılcım Foxfire Projesi'nin başlangıcı olmuştur. Neticede hep birlikte bir sayı dergi çıkarmaya karar vermişlerdir. İlk olarak bir sayılık dergi hedefiyle yola çıkılmasına rağmen Wigginton, bir yandan da bu çalışmanın düzenli bir dergiye dönüşmesi için planlar yapmıştır.

İlk adımda derginin içeriğinin ne olacağına karar vermişlerdir. O dönemde, Apalaş Dağları'nın çevresinde birçok yaşlı insan yaşıyor ve bu insanlar hala ayın evrelerine ve burçlar kuşağına göre ekim yapıyorlardı. Wigginton, bu konuda bazı şeyler duymuştu ama tam olarak ne olduğunu bilmiyordu. Hâl böyle olunca öğretmen, bu konuyu araştırması için öğrencilerine vermiştir. İlk bakışta öğrencilerin bu konuları ebeveynleri ve büyükanne/büyükbabalarından duyup öğrendiklerini düşünmüştür. Ancak öğrencilerin bu konuları hiçbir şey bilmediklerini ve aynı zamanda kendisi gibi bu konuları merak ettiklerini gördükten sonra onlara: "Niçin bu konuyu araştırıp bir makale yazmiyorsunuz?" demiştir. Bunun üzerine öğrenciler, evlerine gitmişler ve akrabalarıyla -bazılarıyla ilk defa- konuşmuşlardır. Bu konuşmalardan onlar; bazı batıl inançlar, eski ev ilaçları, hava durumu işaretleri ve işaretlerle ekim talimatlarının yanı sıra yaban domuzu avıyla ilgili bir hikâye ve bir zamanlar yaşanan yerel bir banka soygunu hakkında emekli bir kasaba polisiyle [şerif] yapılmış bir görüşme kaydıyla gelmişlerdir.

Wigginton, öğrencilerin şiir konusunda derin ön yargılara sahip olduklarını ve hatta şiirden nefret ettiklerini anlamış, onları bu önyargılarından kurtarmak için çalışmanın içeriğine şiiri de eklemiştir. Konuların zamanla netleşmesinden sonra derginin isminin ne olacağı beyin firtınasıyla tartışılmıştır. Bunun için her öğrenciye, üç seçenek sunulmuş, tekrarlar elenmiş ve geriye kalanlar arasında oylama yapılmıştır. Sonunda Apalaş Dağları'nda yaşayan, karanlıkta parlayan, genellikle oradaki dağların gölge kısımlarında görülen minik bir organizma olan "Foxfire" isminde karar kılınmıştır.

İçerik ve isim meselelerinin halledilmesinden sonra daha zor bir konu olan bütçe konusundaki tartışmalara gelinmiştir. O dönemde bulundukları okul, onlara hiçbir şey sağlayacak durumda değildir. Ayrıca ekonomik sorunlar öğrencilerin değil, çalışma fikrini ortaya atan Wigginton'ın sorumluluğudur. Öğrenciler, ya dergiyi satmak ya da 
ilk sayı için para bulmak zorundadır. $\mathrm{Bu}$ durumda öğrenciler, okul çıkışlarında caddelere çıkmış ve miktarına bakmadan bağış toplamaya başlamıştır. Bağış̧̧ıları ikna etmek için bağış yapanlara, kendilerinin imzalayacağı derginin ilk sayısını vereceklerini söylemişlerdir. Süreç sonunda öğrenciler, 50 dolar toplayabilmişlerdir. Bu arada yerel bir matbaanın 6000 kopya için bu paranın yeterli olacağını söylemesi üzerine ilk 6000 adet bastırılmıştır. Şaşırtıcı bir şekilde bütün baskılar, bir haftada satılmış ve hatta 6000 daha ek baskı yaptırmışlardır. Böylece The Foxfire Dergisi, yayın hayatına ilk defa 1968 yılında bu şekilde başlamıştır. Öğrencilerle bir dergi çıkarmanın ve onu ayakta tutmanın kolay olmadığını ve zorlu bir süreçten geçtiklerini söyleyen öğretmen Wigginton, ilk yayın sürecinden derginin uluslararası düzeyde tanınmasına kadar yaşadıklarını şu şekilde özetlemiştir:

Kolay bir süreç değildi gerçekten. Biz her düştüğümüzde biraz daha güçlü kalktık. Şu anda Rabun Gap'ın bir dergisi var. Bu derginin 50 eyalette ve birçok yabancı ülkede aboneleri var. Saturday Review, New Republic, National Geographic, School Bulletin, Scholastic Scope ve Whole Earth Catalogue gibi dergilerde yazılarımız çiktı. National Endowment for the Humanities'ten iki kere hibe aldık. En önemlisi ögrrencilerim, üniversitelere gittiler ve artık yapıcı bir değişim için sorumlu ve etkili şekilde hareket edebileceklerini biliyorlar (Wigginton, 1972, s. 9-12).

Wigginton'ın ifadelerinden de anlaşıldığı gibi lisede başlanan bu proje, öğrencilerin daha önce hayalini bile kuramadıkları üniversite kapılarını aralamalarını sağlamakla kalmamış, onlara değişimi gerçekleştirme konusunda güç veren bir tecrübe olmuştur.

\section{The Foxfire Projesi'nin Başarıları}

The Foxfire Projesi, birçok önemli başarı kazanmıştır. Projenin ilk ve önemli başarısı, The Foxfire adlı bir okul dergisi çıkarmış olmasıdır. Bu dergi, ardından gelen birçok başarının ilk adımı ve motivasyon kaynağı olmuştur. Daha önce de değinildiği gibi derginin ilk sayısının birkaç haftada satılması, öğrencileri oldukça motive etmiş ve onların projeye daha fazla ilgi göstermelerini sağlamıştır. Böylece 1966 yılında bir sayılık dergi çıkarma amacıyla başlanan çalışmalar, zamanla ses getirmiş, The Foxfire Magazine [Dergisi] hızla büyümüştür.

The Foxfire Kitap Serisi: The Foxfire Projesi'ni bir okul dergisinin ötesine taşıyan başarılardan biri de The Foxfire Book adlı kitap serisidir. Bu serinin ilk kitabı olan The Foxfire Book, 1972 yılında Elliot Wigginton editörlüğünde yayımlanmıştır. Bu kitap, öğrencilerin dergi çalışmalarından sonraki ilk önemli başarısı olmuştur. Kitap içeriği tamamıyla öğrencilerin çalışmalarından oluşmuştur. Serinin ilk kitabı, basımından kısa bir süre sonra 5 milyon kopyasının satılmasıyla büyük ilgi çekmiş ve bu serinin (The Foxfire) sonraki kitapları da en çok satılanlar arasına girmiştir (Knapp, 1993). Bu başarıyla başlayan kitap serisinin son kitabı Foxfire 12'nin 2004 yılında yayınlanmasıyla toplamda 12 kitaba ulaşmıştır. Kitapların çoğunda editörlük görevini Elliot Wigginton üstlenmiştir. Bazı kitaplar ise diğer öğretmenler ve öğrencilerle birlikte yayına hazırlanmıştır. 1972-2004 yılları arasında yayımlanan 12 ciltlik kitap serisine ilişkin bazı bilgiler aşağıdaki tabloda özetlenmiştir: 


\section{Tablo 1}

The Foxfire Kitap Serisi ve Özellikleri

\begin{tabular}{|c|c|c|c|c|}
\hline Seri & Başlık & Editör/ler & Konular & Y1l \\
\hline 1. Kitap & $\begin{array}{l}\text { The } \\
\text { Foxfire } \\
\text { Book }\end{array}$ & $\begin{array}{c}\text { Eliot } \\
\text { Wigginton }\end{array}$ & $\begin{array}{l}\text { Domuz pansumanı, kütüklerden kabin yapma, dağ el } \\
\text { sanatları ve yiyecekleri, işaretlerle ekim, yılan bilgileri } \\
\text { ve avcılık hikâyeleri, telkinle [imanla] tedavi, kaçak içki } \\
\text { ve günlük yaşamın diğer işleri }\end{array}$ & 1972 \\
\hline 2. Kitap & $\begin{array}{l}\text { Foxfire } \\
2\end{array}$ & $\begin{array}{c}\text { Eliot } \\
\text { Wigginton }\end{array}$ & $\begin{array}{l}\text { Hayalet hikâyeleri, yabani bitkisel gidalar, iplik çekme } \\
\text { ve dokuma, ebelik, ölü gömme gelenekleri, mısır kabuğu } \\
\text { soyma, vagon yapma ve günlük yaşamın diğer işleri }\end{array}$ & 1973 \\
\hline 3. Kitap & $\begin{array}{l}\text { Foxfire } \\
3\end{array}$ & $\begin{array}{c}\text { Eliot } \\
\text { Wigginton }\end{array}$ & $\begin{array}{l}\text { Hayvan bakımı, banco (müzik aleti) ve santurlar [müzik } \\
\text { aleti], tabaklık [deri işleme], yabani bitkisel gıdalar, } \\
\text { tereyağı yayıkları, ginseng [bitkisel ilaç] ve günlük } \\
\text { yaşamın diğer işleri }\end{array}$ & 1975 \\
\hline 4. Kitap & $\begin{array}{c}\text { Foxfire } \\
4\end{array}$ & $\begin{array}{c}\text { Eliot } \\
\text { Wigginton }\end{array}$ & $\begin{array}{l}\text { Keman yapımı, bahar evleri, at ticareti, sassafras çayı, } \\
\text { meyve kovaları, bahçe ve diğer günlük yaşam işleri }\end{array}$ & 1977 \\
\hline 5. Kitap & $\begin{array}{l}\text { Foxfire } \\
5\end{array}$ & $\begin{array}{c}\text { Eliot } \\
\text { Wigginton }\end{array}$ & $\begin{array}{l}\text { Demir yapımı, nalbantlık, çakmaklı tüfekler, ayı avı ve } \\
\text { diğer günlük yaşam işleri }\end{array}$ & 1979 \\
\hline 6. Kitap & $\begin{array}{l}\text { Foxfire } \\
6\end{array}$ & $\begin{array}{c}\text { Eliot } \\
\text { Wigginton }\end{array}$ & $\begin{array}{l}\text { Ayakkabı yapımı, kabak banço [müzik aleti] ve şarkı } \\
\text { fiyonkları, yüz adet oyuncak ve oyun, ahşap kilitler, } \\
\text { suyla çalışan hızarhane ve diğer günlük yaşam işleri }\end{array}$ & 1980 \\
\hline 7. Kitap & $\begin{array}{c}\text { Foxfire } \\
7\end{array}$ & $\begin{array}{l}\text { Paul F. } \\
\text { Gillespie }\end{array}$ & $\begin{array}{l}\text { Papazlar ve kilise üyeleri, dirilme ve vaftiz töreni, şekilli } \\
\text { not ve kilise şarkısı, telkinle [imanla] tedavi ve dini } \\
\text { toplantılar, yiyecek yıkama ve yılan tutma ritüeli. }\end{array}$ & 1982 \\
\hline 8. Kitap & $\begin{array}{c}\text { Foxfire } \\
8\end{array}$ & $\begin{array}{l}\text { Eliot } \\
\text { Wigginton \& } \\
\text { Margie } \\
\text { Bennett }\end{array}$ & $\begin{array}{l}\text { Çamur karma makinelerinden Güney halk çömleği, kül } \\
\text { sırları, yeraltı kireç firınlarda yapılan testiler, yayıklar, } \\
\text { horozlar, katır takasları ve tavuk kavgası. }\end{array}$ & 1984 \\
\hline 9. Kitap & $\begin{array}{l}\text { Foxfire } \\
9\end{array}$ & $\begin{array}{c}\text { Eliot } \\
\text { Wigginton, } \\
\text { Margie } \\
\text { Bennett \& } \\
\text { onların } \\
\text { öğrencileri }\end{array}$ & $\begin{array}{l}\text { Genel hikayeler, Jud Nelson'un vagonu, bir dua kayası, } \\
\text { bir Catawba Kızılderili çömlekçisi, enfeksiyon } \\
\text { hikayeleri, yorgancılık, ev tedavileri, kabin imalatçısı } \\
\text { ustaları yeniden ziyaret }\end{array}$ & 1986 \\
\hline 10. Kitap & $\begin{array}{c}\text { Foxfire } \\
10\end{array}$ & $\begin{array}{l}\text { George P. } \\
\text { Reynolds \& } \\
\text { Susan W. } \\
\text { Walker }\end{array}$ & $\begin{array}{l}\text { Demiryolu bilgileri, pansiyonlar, buhran dönemi } \\
\text { Apalaşlar, sandalye yapımı, rüzgârgülleri, yılan şekilli } \\
\text { bastonlar ve su kabağı sanatı }\end{array}$ & 1993 \\
\hline 11. Kitap & $\begin{array}{c}\text { Foxfire } \\
11\end{array}$ & $\begin{array}{l}\text { Kaye Carver } \\
\text { Collins \& } \\
\text { Lacy Hunter }\end{array}$ & $\begin{array}{l}\text { Eski yerleşim yerleri, yabani bitki kullanımı, gıdaları } \\
\text { koruma ve pişirme, av hikâyeleri, balıkçılık ve diğer } \\
\text { günlük yaşam işleri }\end{array}$ & 1999 \\
\hline 12. Kitap & $\begin{array}{c}\text { Foxfire } \\
12\end{array}$ & $\begin{array}{l}\text { Kaye Carver } \\
\text { Collins \& } \\
\text { Angie Cheek }\end{array}$ & $\begin{array}{l}\text { Savaş hikâyeleri, Cherokee gelenekleri, yaz kampları, } \\
\text { kare dans [dörder çiftten oluşan grupların yaptığı bir } \\
\text { dans], el sanatları ve diğer günlük yaşam işleri }\end{array}$ & 2004 \\
\hline
\end{tabular}

Görüldüğü gibi öğrenciler, Apalaş Dağları'nın kültürünü insanların tanıklıklarına dayanarak ve çeşitli konulara ayırarak araştırmışlardır. Öğrenciler, 
buradaki çalışmalarda çeşitli sözlü tarih çalışma türlerinin kullanmışlardır. Öncelikle onların çalışmalarının büyük bölümü, kültür araştırmasına (kültür gazeteciliğine) dayanmaktadır. İkinci olarak onlar, kişilik araştırmaları yapmışlardır. Öğrenciler, bu çalışma türünde kaynak kişiyle detaylı bir şekilde görüşmüşler ve ondan çeşitli tarihi materyaller almışlardır. Toplanan verilerin analizi neticesinde hayatı araştırılan bir kişinin hayat öyküsüne kitap serisinin kitaplarında yer vermişlerdir. Örneğin; The Foxfire Book (1. kitap) kitabında Aunt Arie'nin hayat hikâyesi, tecrübeleri ve hayatında zaman içinde nelerin değiştiği derinlemesine ele alınmıştır.

Fotoğraf 1: Aunt Arie Evinin Balkonunda Otururken

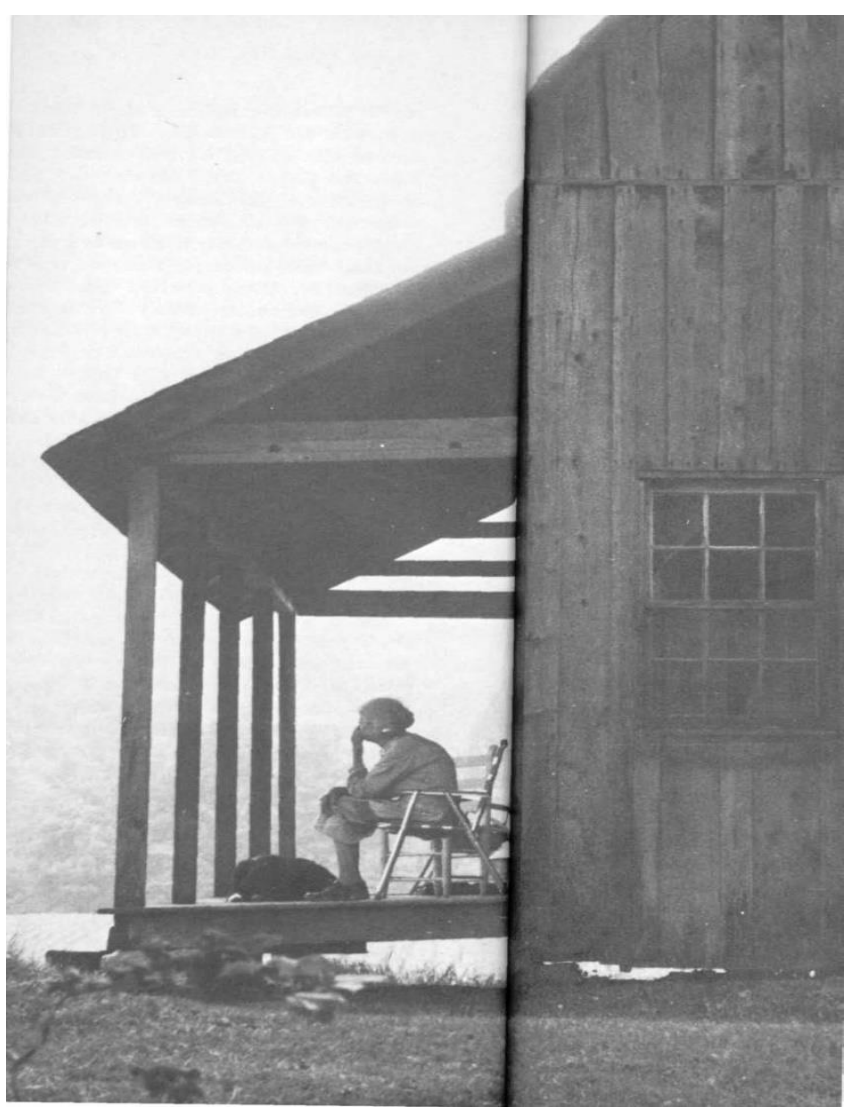

Kaynak: Wigginton, 1972, s. 25

\section{Sözlü Tarihin Eğitim Uygulamalarına Entegrasyonu}

Sözlü tarih, ilk olarak 1948 y1lında Allan Nevins'1n Kolombiya Üniversitesi'nde Sözlü Tarih Ofisi'ni açması ve tarih bölümündeki öğrencilerin sözlü tarih projelerine dahil edilmesiyle eğitime entegre edilmeye başlanmıştır. Bu akım, kısa sürede diğer üniversitelere yansımış ve çeşitli bilim insanları sözlü tarihi derslerinde bir yöntem olarak kullanmaya başlamıştır (Starr, 1977). Üniversitelerde başlayan bu çalışmalar, liselerden ilkokullara kadar yayılmıştır. Bu akımın önemli örneklerinden biri olan The Foxfire Projesi, sözlü tarihin eğitim uygulamalarıyla nasıl bütünleştirildiğini açıklayan önemli kaynaklardan biridir.

Daha önce değinildiği gibi The Foxfire Projesi’nde öğrenciler, görüşmeler yaparak sözel verilere ve tarihi materyallere ulaşmışlardır. Ancak buraya kadar bir sözlü tarih sürecinin sınıftan saha çalışmasına kadar hangi aşamalardan geçtiğine değinilmemiştir. Peki, bu projede ulaşılan veriler, nasıl değerlendirilmiş, eğitim ve öğretim yöntemi olarak sözlü tarihi derslere nasıl entegre edilmiştir? Bu noktada bu 
sorulara cevap vermekte fayda vardır. The Foxfire Projesi'nde siradan bir dönem, bir sömestr sonunda bitirilirdi. Öncesinde öğrenciler, görüşmelere başlar, sesli olarak okunan bir hikâyeyi dinler ve duydukları her şeyi yazmaya çalışırlardı. Bu okuma parçalarının bir örneğinin, orijinal hikâyenin herhangi bir parçasından daha zengin ve geniş olduğu görüldüğünde, benzer hikâyeler yavaşça yeniden okunurdu. Öğrenciler ise yine okunan metni not almaya çalışırdı. Bu alıştırmalar, problemin dinlemede ve kaydedilen görüşmelere açıklık getirme ihtiyacında olduğunu gösterirdi. Daha sonra öğrenciler, döküm pratikleri yaparlardı. Diğer sınıf oturumları ise farklı kaydediciler ve mikrofonlar gibi ekipmanların uygun şekilde nasıl kullanılacağına ilişkin denemeleri kapsard1.

Bir The Foxfire sınıfındaki öğrenciler, kimle görüşeceğini ve soracağı sorulara ilişkin proje konusunu öğretmen Wigginton'dan öğrenirdi. Öğrenciler, görüşmeye çıkmadan önce tecrübe kazanmak için sınıfa davet edilen herhangi biriyle -belki başka bir öğretmen, bir okul yöneticisi, kantin çalışanı ya da bir veli- sınıf içi görüşme pratiği yapard1. Bu etkinlikte öğrenciler, bir görüşmeci olarak görüşme sırasında üstleneceği sorumluluklarını yerine getirmeyi öğrenirlerdi. Ayrıca farklı döküm tarzlarının görüşmenin içeriği üzerindeki etkilerini de analiz etmeyi ve yazıya dökerken dikkatsiz davranan bir kişinin görüşmenin içeriğini nasıl değiştirdiğini fark etme imkânı bulurlardı. Çünkü görüşme pratiği yapılırken diğer öğrenciler not alarak görüşmeyi takip ederlerdi. Bütün bu sınıf içi denemeler ve tartışmalarla konuyu kavrayan öğrenciler, sonunda tek başlarına görüşmeye gitmek için hazır hâle gelirlerdi (Ritchie, 2015).

Sınıf içinde bu aşamalardan geçerek görüşmeye hazırlanan öğrenciler, ilk görüşmelerine büyükleriyle birlikte gönderilirdi. İlk görüşmelerde kısa ve karmaşık olmayan (basit) konularda tecrübe ve özgüven kazanan öğrenciler, zamanla tek başlarına görüşme yapmaya başlarlardı. Nitekim öğretmen Wigginton, öğrencilerin nasıl veri topladıklarını ve verileri yayına nasıl hazırladıklarını şu şekilde aktarmıştır:

Çok farklı yazılar oluşturuyoruz... Bir ara bir dergiden bizi aradılar ve bu yıl havanın nasıl olacağını bilmenin farklı yollarını anlatan bir yazı hazırlıyoruz, dediler. Dosyada altı ya da sekiz yazımız vardı. Tamam, öğleden sonra 3.30 'da tekrar arayın, sizin için bir şeyler hazırlamış olacağız, dedik. İki ders saatini ayırırsınız ve dergide çalışan çocukların hemen hepsini -elli beş çocuğu- çağırırsınız ve şöyle dersiniz: <Çocuklar şimdi siz Kelly Deresi'ni alıyorsunuz, siz de Betty Deresi'ni... Çıkıp, karşınıza çıkan herkese hatırladıkları hava durumu işaretlerini soruyorsunuz ve bir saat kırk beş dakika içinde geri dönüyorsunuz.> Bir saat kırk beş dakika içerisinde hiç farkında olmadığımız 110 hava durumu işareti topladık...

Yaptığımız bir başka görüşme kişilik tipi görüşmesidir. Genellikle her sayıda bir kişiye yer veririz. Bu sayıda bizim bölgede yaşayan Ada Kelly adında bir büyükanneye yer veriyoruz. Ada Kelly makalesinden sorumlu çocuklar onunla en az üç ya da dört kez görüşecekler... Çocuklar her şeyi kendileri örgütleyip sunacaklar... (Thompson, 1999, s. 155-157).

Wigginton'dan yapılan alıntının ilk bölümünden anlaşılacağı gibi öğrenciler, süreç içinde kendilerini oldukça geliştirmişler, dergiden beklenen 5-6 yazıyı iki saatlik bir çalışma neticesinde toplayabilecek pratikliğe kavuşmuşlardır. Bu çalışma türü, Türkiye'de halk bilimcilerin ve coğrafyacıların halktan topladıkları hava ve iklim tahmin ve tekniklerini birleştirdikleri halk takvimi ya da halk meteorolojisi olarak da bilinen eserlerle benzerlik göstermektedir. Nitekim Gürbüz Erginer’in hazırladığ 1 Uşak Halk Takvimi Halk Meteorolojisi (Erginer, 1984) adlı folklorik derleme bu türün 
örneklerinden biridir. Bu kitapta Uşak halkının hava tahminleri ve mevsimlerle ilgili tecrübeleri bir araya getirilmiştir.

Alıntının ikinci parçasında yer verilen sözlü tarih çalışma tipi ise otobiyografik sözlü tarih çalışmasının özelliklerini taşımaktadır. Otobiyografik çalışmalarda kişilerin kendi hayatları hakkında verdikleri bilgiler toplanarak hayat hikâyesi oluşturulur (Hoyle, 1972). Her iki sözlü tarih çalışma türünün örneklerine hem öğrencilerin dergilerde yazdığ 1 yazılarda hem de -Tablo 1'de detaylı şekilde sunulan- yayımlanan The Foxfire kitaplarında oldukça sık rastlanmaktadır.

Görüldüğü gibi öğrenciler, öncelikle sınıf içi uygulamalarla sözlü tarihin ne olduğunu iyi bir şekilde kavradıktan sonra sahaya çıkarak veriler toplamış, bu verileri analiz etmiş ve çeşitli eserlere dönüştürmüşlerdir.

\section{The Foxfire Projesi'nin Yansımaları}

The Foxfire Projesi'nde öğrencilerin kazandığı başarılar, doğal olarak diğer okul projelerine de ilham kaynağı olmuştur. The Foxfire, bir "saha çalışması girişimi" olarak yalnızca kendi başarısıyla sınırlı kalmamış, aynı zamanda toplum-okul ilişkilerinde ve görüşme eğitiminde önerdiği mesajı diğer okullara da yaymıştır. The Foxfire Book serisinin ilk kitabının yayımlanmasından esinlenen sayısız okul; sözlü tarihi halk bilimini ve yerel tarihi birleştiren benzer dergiler çıkarmıştır (Ritchie, 2015). Örneğin; Amerika'nın Kanada sınırında bulunan Main eyaletinin Kennebunk şehrinde bir grup öğrenci, Pamela Wood'un danışmanlığında okul gazetesi şeklinde başladıkları çalışmalarını, 1977 yılında The Salt Book adıyla yayımlamıştır. Bu kitapta öğrenciler, New England'daki günlük yaşamın unsurlarını ele almışlardır. Fotoğraflarla ve şekillerle desteklenen bilgiler, bölgedeki insanların hikâyelerini de barındırmaktadır (Wood, 1977). Bu serinin ikinci kitabı ise 1980 yılında yine Pamela Wood editörlüğünde Salt 2: Boatbuilding, Sailmaking, Island People, River Driving, Bean Hole Beans, Wooden Paddles, and More Yankee Doings adıyla yayımlanmıştır (Wood, 1980).

Fotoğraf 2: The Salt Book Kitab1

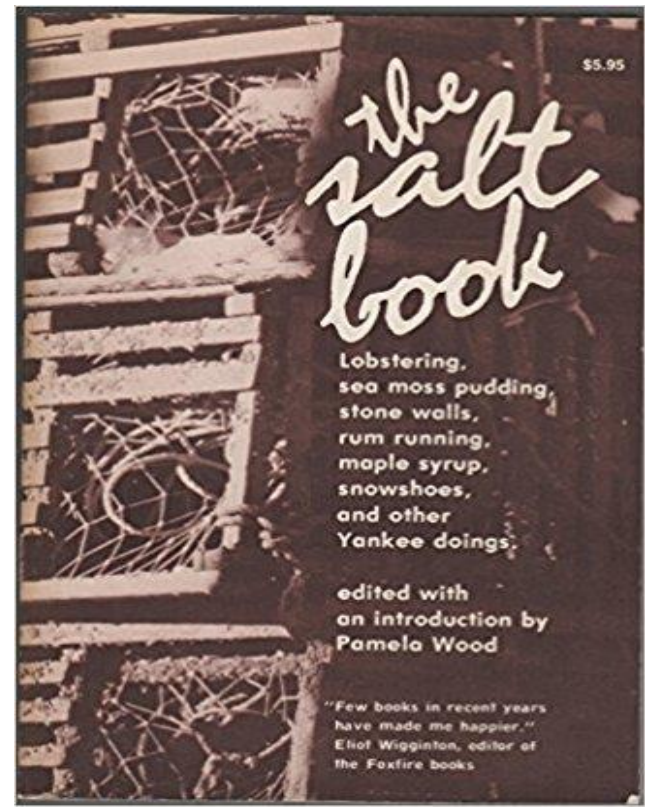

Kaynak: www.amazon.com 
Diğer bir örnekte Amerika'nın Kaliforniya eyaletinin Bell Gardens şehrinde ortaokul öğrencilerinin yerel tarih çalışmaları, Bittersweet County: Long, Long Ago adıyla bir kitapta toplanmıştır. Ayrıca Kuzey Kaliforniya'nın Anderson Valley şehrinde, 8. sınıf öğrencilerinin bölgedeki kişilerle yaptıkları görüşmeleri içeren çalışmaları, Voice of the Valley adıyla yayımlanmıştır. Diğer bir örnekte Kolorado eyaletinin Littleton kasabasında, öğrencilerin Aspen Glow, Boulder'daki tarla işçilerinin çocukları hakkındaki çalışması, El Aguile adıyla basılmıştır. Ayrıca Mississippi eyaletinde, ülkenin en fakir kentlerinden biri olan Holmes County'de, öğrenciler Bloodliness adlı sözlü tarih dergisini çıkarırken, Maryland eyaletinin güneyinde öğrenciler, tütün çiftçileri ve kayıkçılarla yaptıkları görüşmelerini Slackwater adıyla yayımlamışlardır (Ritchie, 2015).

Amerika'da sözlü tarih geleneğinin en köklü kurumlarından birine sahip olan Kaliforniya eyaletinin Theodore Roosevelt Lisesi'nde öğretmen Howard J. Shorr'ın önderliğinde bir proje geliştirilmiştir. Seçmeli bir ders kapsamında yapılan projede öğrenciler, bir sömestr boyunca "The History of Boyle Heights” başlığıyla Doğu Los Angeles toplumu bağlamında Kaliforniya'yı, Amerika'yı ve dünyayı değerlendiren bir çalışma yapmışlardır. Öğrenciler, projelerini oluşturduklarında birçok taslak, dipnot ve kaynağı içeren sonuç raporları ortaya çıkmıştır. Hem geleneksel kaynakları hem de sözlü kaynakların kullanıldığı çalışmalarda, "Relocation of Japaneese", "1963-1968 The Explosive Era" ve "War on Poverty" temalarına odaklanılmıştır. Bu proje sayesinde öğrencilerin tarihe olan saygısı artmış, yazma ve araştırma konularında özgüvenleri gelişmiştir (Lanman \& Mehaffy, 1988). Örnek dergi çalışmaları ve projeler, zamanla geliştirilmiş ve yeni projelerin verileri birçoğu internet ortamına aktarılmıştır. Ancak bu dergi ve projelerin çoğu uzun süre varlığını koruyamamış, bazı okullar kendi imkânlarıyla bazı projeler yapmaya devam etmiştir (Ritchie, 2015).

1990'l1 y1llardan itibaren The Foxfire Projesi sayesinde eğitime entegre edilen sözlü tarih yöntemini diğer öğretmenlere öğretmek için The Foxfire Öğrenme ve Öğretme Yaklaşımı Programı (The Foxfire Approach to Teaching and Learning) adlı öğretim programı başlatılmıştır (Harell, 2016). Sözlü tarihi kendi sınıfında kullanmak isteyen birçok öğretmen bu programa katılarak eğitim almıştır. Bu eğitimlere katılan öğretmenlerden biri olan Susan Moon, Georgia eyaletinin Barnesville kentinin Lamar County Lisesi'nde İngilizce ve İspanyolca derslerinde sözlü tarihi kullanmıştır. Moon ve öğrencileri, The Foxfire yöntemiyle [yani sözlü tarih] bir okul gazetesi, edebi dergi ve ayrıca kasaba insanlarının sözlü tarih koleksiyonlarını çıkarmışlardır. Bunun yanında büyükannelerinin ve büyükbabalarının masallarını Yaşlıların Masalları adıyla yayımlamışlardır (Kuhn, 1997). Yani öğretmen Moon, The Foxfïre Öğrenme ve Öğretme Yaklaşımı Programı'nda öğrendiklerini sınıfında uygulamış ve öğrencileriyle birlikte çeşitli eserler ortaya koymuştur. Bu örneklerin ötesinde Amerika'da 1200'den fazla öğretmen, The Foxfire tarzı dergi çalışmasını öğrenme aracı olarak kullanmaya başlamıştır (New York Times, 13 Aralık 1993).

The Foxfire Projesi, eğitime kazandırdığı bakış açısı ve sunduğu sistemle Amerikan eğitim tarihinin en eski ve en geniş yer temelli eğitim reformu modellerinden biri olarak anılmaktadır (Gruenewald, 2005). Ayrıca proje kapsamında öğrencilerin çabası ve toplumun katkılarıyla kurulan ve zaman içinde geliştirilen The Foxfire Müzesi ve Miras Merkezi 1974 yılında kurulmuştur. Bu kurum, halen hizmet vermeye devam etmektedir. Şuanda müzeye ait 30 bina bulunmaktadır (Stiles, 2016). Bunlara ek olarak 
The Foxfire Projesi, bir Broadway oyununa dahi ilham kaynağı olmuştur (New York Times, 13 Aralık 1993). Son olarak bu proje, hâlâ günümüzdeki projelere ilham olmaya devam etmektedir. Örneğin; Apalaş kültürünün ve geleneklerinin The Foxfire Projesi'nde olduğu gibi kaydedilmesi ve korunması için The North Georgia Program adlı proje başlatılmıştır (Atlanta Magazine, 2017).

\section{Tartışma ve Sonuç}

Sözlü tarih; uzun yıllardır Amerika, İngiltere ve Kanada gibi ülkelerde bir öğrenme ve öğretme yöntemi olarak kullanılmaktadır. Eğitim uygulamalarında sözlü tarih; öğrencilerin amatör birer tarihçi olarak titizlikle ve yaratıcılıkla ulaştıkları verilerin üzerinde düşünmelerini (Hoopes, 1984; McLellan, 2014), derslerin içeriğini öğrenmesini, kendi toplumlarının yaşamı ve geçmişi arasındaki kişisel bağlantıyı kurmasın1, araştırma ve temel yazma becerilerini geliştirmelerini sağlayan (Ardemendo \& Kuszmar, 2009) yapılandırmacı bir öğrenme ve öğretme yöntemi (Dere \& Dinç, 2018) olarak önemli bir yere sahiptir.

Eğitimde sözlü tarih çalışmaları, genelde bir proje kapsamında yapılmaktadır. Yapılan bu projelerin en ünlüsü, Cornell Üniversitesi'nden 1966 yılında mezun olan Eliot Wigginton tarafindan Georgia Eyaleti'nde hizmet veren Rabun Gap-Nacoochee Lisesi'nde başlatılan The Foxfire Projesi'dir. Bu projede Wigginton, okuldaki diğer öğretmenlerin 'umutsuz vakalar' olarak yaftaladığı ilgisiz öğrencileri, motive etmiş ve onlarla birlikte bir okul dergisi kurmuştur. Bu dergi ve proje, zaman içinde gelişerek ülke ve dünya çapında bir bilimsel dergi hüviyeti ve ün kazanmıştır. Ayrıca bu proje kapsamında öğrencilerin sözlü tarih çalışmalarını bir araya getiren ve büyük bölümü Wigginton tarafından düzenlenen 12 ciltlik kitap serisi çıkarılmıştır. $\mathrm{Bu}$ serinin ilk kitabı, The Foxfire Book, 5 milyon satarak en çok satan kitaplar arasına girmiştir. Bunlarla birlikte Saturday Review, New Republic, National Geographic, School Bulletin, Scholastic Scope ve Whole Earth Catalogue gibi birçok önemli bilimsel dergide öğrencilerin yaptığı çalışmaların sonuçları yayımlanmıştır. Yine proje kapsamında yapılan çalışmalarda toplanan tarihi materyaller ve öğrenciler tarafından üretilen eserlerin sergilendiği bir müze ve miras merkezi kurulmuştur. Dahası bu proje kapsamında zaman içinde geliştirilen öğrenme ve öğretme tecrübeleri, The Foxfire Öğrenme ve Öğretme Yaklaşımı Programı (The Foxfire Approach to Teaching and Learning) adıyla bir modele dönüştürülmüştür. The Foxfire Öğrenme ve Öğretme Yaklaşımı Programı kapsamında yaklaşımın uygulama ilkeleri ve derslerinde kullanabilecekleri materyaller günümüzde de öğretmenlere hizmet sunmaya devam etmektedir.

Türkiye'de çeşitli araştırmalarda sözlü tarih ele alınmasına rağmen okul projeleri yeterince yaygınlaşmamıştır. Okul projelerinin gerçekleştirilmesinde yol gösterici çalışmalara ve örneklere ihtiyaç duyulmaktadır. Bu manada The Foxfire Projesi, ilham verici bir iyi örnek olma potansiyeline sahiptir. Bu proje, bölgenin iç kaynaklarıyla gelişmiş ve büyümüştür. Yani önemli finansal kaynaklar olmadan da okul temelli sözlü tarih projelerinin gerçekleştirilebileceğini göstermektedir. Ayrıca ilgisiz öğrencileri derse katma, onlara üretme fırsatı sunma ve sorumluluk değerini kazandırma konularında da önemli katkılara sahiptir. Öğretmen Wigginton, kendi okulundaki öğretmenlerin 'umutsuz vakalar' olarak yaftaladı̆̆ı ilgisiz öğrencilerle bu projeyi gerçekleştirmiş ve büyük başarılar kazanmıştır (Wigginton, 1972). 
Türkiye'de sözlü tarihin okullu temelli projelerde kullanılabilmesi için öncelikle Milli Eğitim Bakanlığı'nın ders kitaplarında bu yöntemin nasıl kullanılabileceğine dair örneklere yer verilmesi gerekmektedir. Ayrıca sözlü tarih projeleri için bütçe destekleri sağlandığında ve proje yapan öğretmenler teşvik edildiğinde, okullu temelli sözlü tarih projelerinin artış göstermesi beklenebilir. Bunların yanında sivil toplum ve okulların bulunduğu çevredeki yerel halkla iş birliği yapılabilir ve onların tecrübelerin okullarda verilen eğitimin bir parçası haline getirilebilir. Son olarak sözlü tarih projelerinde çalışan ögrencilerin ailelerin sürece dâhil edilmesi, okul temelli sözlü tarih projelerinin olmazsa olmazidir.

Sonuç olarak değerlendirildiğinde, sözlü tarih, gerek öğrencilere katkıları gerekse öğretmenlerin derslerini etkili bir şekilde sürdürmeleri için sunduğu olanaklar bakımından oldukça değerli bir yöntemdir. Bu önemli yöntemin okul temelli projelerle birlikte yürütülmesi, bu katkıları okulun dışına taşımakta ve topluma artı değer katmaktadır. $\mathrm{Bu}$ önemle The Foxfire Projesi kapsamında üretilen kitaplar, kurulan müze, öğrenme ve öğretme ilkeleri daha sonraki çalışmalarda daha ayrıntılı olarak ele alınmalı ve Türkiye şartlarına uyarlanmalıdır. Bunu başarabilmek için öncelikle bu proje, Türkiye'de daha geniş şekilde incelenmelidir. 


\section{Summary}

Purpose and Significance: Oral history collects data by recording persons' memories and testimonies. The method is used as a data collection tool in many social sciences fields, such as history, sociology, journalism, and folklore. In addition, it is integrated into educational practices as learning or teaching method. The integration process in the field of education began with the opening of Oral History Office in Columbia University by Allan Nevins in 1948. Shortly after the opening of this office, it began to be used as a classroom method in high school, middle school, and even in elementary school. In addition, a variety of school-based oral history projects has been done. The most prominent of these projects is The Foxfire Project, initiated by Eliot Wigginton, who began his career at the Rabun Gap-Nacoochee High School, Georgia, in the United States where he graduated from Cornell University in 1966. In this project, he motivated the uninterested students who were labeled by their own teachers in the school as 'hopeless cases'. One day, he said to his own students "Would you all like to leave the textbooks aside and issue a magazine?", and he issued a school magazine with them. The students who brainstormed for it named the magazine as "Foxfire". Following the recognition of the magazine's name, Wigginton distributed the students a variety of topics that they could interview with elderly people in the region. Later, the students brought into the class the data they collected from their interviews with their families and relatives. Then, analysis and interpretations made by the students and the teacher were published in The Foxfire Magazine. The first 6000 of the magazine have been sold in a few weeks. The Foxfire Book transformed this successful adventure into a book series in 1972. This project has been continuing without interruption since 1966. Naturally, it is followed by scholars related to oral history in the United States and all over the globe, but in Turkey, few scholars knowing that The Foxfire Project is the most famous school-based oral history project around the world. For this reason, the aim of this study is to show the success story of The Foxfire Project, the pioneer of schoolbased oral history projects, from beginning to the present. This project has been studied in detail in this work for the first time in Turkey.

Method: The method of document analysis, one of the qualitative research methods, has been preferred in this study. The method was chosen because The Foxfire Project was examined through written and visual materials that included the development process of the project, the books published in the project, the outputs of the project, and its educational reflections. In this context, all the works and studies written about the project from 1966 the present were tried to get access. Within this framework, the 12volume The Foxfire book series, the activities of the project, its achievements, the perspectives added by the project to educational implementations were addressed. Descriptive analysis method was conducted to assess and interpret the data.

Discussion and Conclusion: At the end of the data analysis, some important results have been figured out about The Foxfire Project. First, the Foxfire, which started as a school magazine in 1968, earned a national and international scientific journal identity and reputation. Second, 12-volume series of books were published, edited by Elliot Wigginton most of which, in order to gather together oral history studies of students. The first book of this series, The Foxfire Book, sold five million and became a 
bestseller. Third, the students' oral history studies in many important scientific journals like in the Saturday Review, New Republic, National Geographic, School Bulletin, Scholastic Scope, and Whole Earth Catalog were published. Fourth, museum and heritage center was established to exhibit artifacts producing and historic materials gathered by students during the studies conducted within the scope of the project. Fifth, the learning and teaching experiences developed over time under the project have been transformed into a model called The Foxfire Approach to Teaching and Learning. Within The Foxfire Learning and Teaching Approach Program, the principals of the approach to teachers and the materials they can use in their lessons were taught. In addition, this project is recognized as one of the oldest and largest applied education reform models in the American education history. Finally, the project inspired many schools in the United States to make similar school-based projects and to issue school magazines. As mentioned before, The Foxfire Project has a very important place in the integration of oral history into educational practices. The recognition of this project in Turkey has the potential to make an important contribution to the expansion of schoolbased oral history projects. In this respect, the books, museums, learning and teaching principles produced within the scope of this project should be dealt with in more detail in later studies and adapted to the Turkish conditions. 


\section{Kaynakça}

Abrams, L. (2010). Oral history theory. London: Routledge.

Akçalı, A. A. (2007). Yerel tarih ve tarih eğitimine katkısı (Yayımlanmamış Yüksek Lisans Tezi). Dokuz Eylül Üniversitesi, Eğitim Bilimleri Enstitüsü, İzmir.

Ardemendo, D., \& Kuszmar, K. (2009). Principles and best practices for oral history education (4-12). Washington DC: Oral History Association (OHA), 1-3.

Arslan, Y. (2012). Yerel ve sözlü tarihin ortaöğretim ögrencilerindeki yansımalart: Tunceli Merkez örneği (Yayımlanmamış Doktora Tezi). Marmara Üniversitesi, Eğitim Bilimleri Enstitüsü İstanbul.

Atlanta Magazine, (2017). At 50, Foxfire has a new generation of fans. Retrieved on 14/05/2017 from http://www.atlantamagazine.com/news-culture-articles/50foxfirenew-generation-fans/

Benison, S. (1984). Introduction to Tom Rivers. In David K. Dunaway, D. K., \& Baum,

W. K. (Eds.), Oral history: An interdisciplinary anthology (pp. 124-130).

Nashville, Tennessee: American Association for State and Local History.

Bilim ve Sanat Vakfi [BİSAV), (2018). Sözlü tarih çalışmaları. http://www.sozlutarih.org.tr/sozlutarihmenu/5 sitesinden 04/04/2018 tarihinde alınmıştır.

Caunce, S. (2001). Sözlü tarih ve yerel tarihçi (çev. Bilmez Bülent Can, Alper Yalçınkaya; yay. haz. Ayşe Özil). İstanbul: Türkiye Ekonomik ve Toplumsal Tarih Vakfi.

Charlton, T. L., Myers, L. E., \& Sharpless, R. (Eds.) (2006). Handbook of oral history. Lanham, MD: Altamira Press.

Collins, K. C., \& Cheek, A. (2004). Foxfire 12: War stories, Cherokee Traditions, summer camps, square dancing, crafts, and more affairs of plain living. New York: Anchor Books.

Collins, K. C., \& Hunter, L. (1999). Foxfire 11: The old home place, wild plant uses, preserving and cooking food, hunting stories, fishing, and more affairs of plain living. New York: Anchor Books.

Çepni, S. (2012). Araştırma ve proje çalışmalarına giriş. Trabzon: Celepler Matbaacilik.

Dere, İ. (2017). Sosyal bilgiler derslerinde bir öğrenme ve ögretme yöntemi olarak sözlü tarih (Yayımlanmamış Doktora Tezi). Uşak Üniversitesi Sosyal Bilimler Enstitüsü.

Dere, İ. (2018). Sosyal bilgiler öğretim programlarında (2005 ve 2017) sözlü tarih. Milli Ĕ̆itim Dergisi, 47(219), 33-56.

Durmuş, K. (2013). Öğretmenlerin ve mezunların bakış açılarından Ermeni azınlık okullarında tarih ögretimi (Yayımlanmamış Yüksek Lisans Tezi). Marmara Üniversitesi Eğitim Bilimleri Enstitüsü.

Dere, İ., \& Dinç, E. (2018). Yapılandırmacı bir öğrenme ve öğretme yöntemi olarak sözlü tarihin sosyal bilgiler derslerine entegrasyonu. İnönü Üniversitesi Eğitim Fakültesi Dergisi, 19(2), 115-127.

Ekiz, D. (2007). Bilimsel araştırma yöntemleri. İstanbul: Lisans Yayınevi. 
Erginer, G. (1984). Uşak halk takvimi, halk meteorolojisi. Türk Tarih Kurumu Basımevi.

Evans, G. E. (1956). Ask the fellows who cut the hay (First Edition edition). Faber \& Faber.

Gillespie, P. F. (1982). Foxfire 7. Garden City, N.Y: Anchor Press/Doubleday.

Gregson, S. (2009). Oral historian and activist, 'Studs' Terkel (1912-2008). Labour History, 96, 233.

Grele, R. J., \& Terkel, S. (1985). Envelopes of sound: The art of oral history. Chicago, IL: Precedent Pub.

Gruenewald, D. A. (2005). Accountability and collaboration: institutional barriers and strategic pathways for place-based education. Ethics, and Environment, 8(3), 261283.

Harell, K. (2016). The Foxfire course for teachers. In Smith, H., \& McDermott, J. C. (Eds.), The Foxfire approach: Inspiration for classrooms and beyond (pp. 101113). Sense Publishers.

Hoopes, J. (1984). Oral history for the student. In Dunaway, D. K., \& Baum, W. K. (Eds.) Oral history: an interdisciplinary anthology. (pp. 349-355). Nashville, Tennessee: American Association for State and Local History.

Hoyle, N. (1972). Oral history. Library Trends, 21(1), 60-82.

Işık, H. (2008). İlköğretim 4. sınıf sosyal bilgiler tarih konularının ögrretiminde kanıt temelli ögrenme modeli: Bir aksiyon araştırması (Yayımlanmamış Yüksek Lisans Tezi). Marmara Üniversitesi Eğitim Bilimleri Enstitüsü, İstanbul.

İbn Haldun Üniversitesi, (2018). Türkiye'de din, devlet, toplum ve hafıza: 1923-1950. http://sozlutarih.ihu.edu.tr/arastirma-projeleriturkiyede-din-devlet/ sitesinden 03/04/2018 tarihinde alınmıştır.

İncegül, S. (2010). Sosyal bilgiler dersinde örnek bir sözlü tarih uygulaması (Yayımlanmamış Yüksek Lisans Tezi). Marmara Üniversitesi Eğitim Bilimleri Enstitüsü, İstanbul.

İzmir Büyükşehir Belediyesi, (2013). "Gençler Yaşlılar El Ele" projesi. http://www.sabah.com.tr/egeli/2013/03/02/buyuksehirde-sozlu-tarih-projesi sitesinden 13/02/2017 tarihinde alınmıştır.

Kafkas Vakfı, (2014). Köklerini arayan fidan sözlü tarih projesi. https://www.kafkas.org.tr/proje/sozlu-tarih/ sitesinden 13/02/2017 tarihinde alınmıştır.

Kaplan, E. (2005). İlköğretim öğrencilerinin tarihsel düşünce becerilerinin sözlü tarih çalışmalarıyla geliştirilmesi (Yayımlanmamış Yüksek Lisans Tezi). Marmara Üniversitesi Eğitim Bilimleri Enstitüsü, İstanbul.

Kaya, M. (2013). Sosyal bilgiler dersinde kullanılabilecek bir ögretim yöntemi olarak sözlü tarih: amaç, içerik, uygulama (Yayımlanmamış Yüksek Lisans Tezi). Marmara Üniversitesi Eğitim Bilimleri Enstitüsü, İstanbul.

Knapp, C. E., \& Wigginton, E. (1993). An interview with Eliot Wigginton: Reflecting on the Foxfire approach. The Phi Delta Kappan, 74(10), 779-782.

Kumru, G. (2009). Tarih ögretimi açısından sözlü tarih yazımı: Karaca Ahmet Dergâhı 
örneği (Yayımlanmamış Yüksek Lisans Tezi). Marmara Üniversitesi Eğitim Bilimleri Enstitüsü.

Küpüç, E. (2014). Sözlü tarih kavramı ve sözlü tarihin tarih ögretimindeki rolü (Yayımlanmamış Yüksek Lisans Tezi). Yüzüncü Yıl Üniversitesi Eğitim Bilimleri Enstitüsü, Van.

Lanman, B. A., \& Mehaffy, G. L. (1988). Oral history in the secondary school classroom. The Oral History Review, 16, 2.

McLellan, H. (1996). Situated learning perspectives. Englewood Cliffs, New Jersey: Educational Technology Publications, Inc.

McLellan, M. L. (2014). Beyond the transcript: oral history as pedagogy. In Boyd, D., \& Larson, M. (Eds.), Oral history and digital humanities: voice, access, and engagement. (pp. 99-118). USA: Springer.

Metin, E. (2007). Geçmiş zaman istasyonu 1: Sözlü tarih treni. Çankırı: Çankırı Belediyesi Gençlik Meclisi.

Millî Eğitim Bakanlığı [MEB], (2006). Sosyal bilgiler 6.-7. sinıflar öğretim programı. Ankara: TTKB Yayınları.

Mitchell, J. (1996). Joe Gould's secret. New York: Modern Library.

New York Times, (13 Aralık 1993). 'Foxfire Book' teacher admits child molestation. Retrieved on 14/05/2017 from https://www.nytimes.com/1992/11/13/us/foxfirebook-teacher-admits-child- molestation.html

Özer, E. (2012). Sosyal bilgiler dersinde yerel ve sözlü tarih etkinliklerinin programlanması (Yayımlanmamış Yüksek Lisans Tezi). Necmettin Erbakan Üniversitesi Eğitim Bilimleri Enstitüsü.

Öztaşç1, C. A. (2017). Yerel tarih öğretim yöntemini sosyal bilgiler dersinde uygulamaya koymak: Bir eylem araştırması (Yayımlanmamış Yüksek Lisans Tezi). Marmara Üniversitesi Eğitim Bilimleri Enstitüsü, İstanbul.

Öztürkmen, A. (2002). Sözlü tarih: Yeni bir disiplin cazibesi. Toplum ve Bilim, 91, 115121.

Reynolds, G. P., \& Walker, S. W. (1993). Foxfire 10: Railroad lore, boarding houses, Depression-era Appalachia, chair making, whirligigs, snake canes, and gourd art. New York: Doubleday.

Ritchie, D. A. (2015). Doing oral history (3th Edition). New York: Oxford University Press.

Kuhn, C. (1997). Voices of experience: Oral history in the classroom. OAH Magazine of History, 11(3), 23-31.

Safran, M., \& Ata, B. (1998). Okul dışı tarih öğretimi. G̈̈ Gazi Eğitim Fakültesi Dergisi, 18(1), 87-94.

Sarı, İ. (2002). Sosyal bilgiler dersi tarih ünitelerinde bir yöntem olarak sözlü tarih (Yayımlanmamış Yüksek Lisans Tezi). Gazi Üniversitesi Eğitim Bilimleri Enstitüsü, Ankara.

Sarı, İ. (2007). Sosyal bilgiler öğretiminde sözlü tarih etkinliklerinin öğrenci başarl, beceri ve tutumlarına etkisi (Yayımlanmamış Doktora Lisans Tezi). Gazi Üniversitesi, Eğitim Bilimleri Enstitüsü, Ankara. 
Shaughnessy, D. F. (1960). Labor in the oral history collection of Columbia University. Labor History, 1(2), 177-195.

Starr, L. (1977). Oral History. Encyclopedia of library and information science, C. 20, 440-463.

Stiles, B. (2016). The Foxfire Museum and Heritage Center. In Smith, H., \& McDermott, J. C. (Eds.). The Foxfire approach: Inspiration for classrooms and beyond (pp. 11-12). Sense Publishers.

Tarih Vakfi, (2018). Sözlü çalışmaları. http://tarihvakfi.org.tr/Proje/sozlutarihcalismalari/12 sitesinden 24/05/2018 tarihinde alınmıştır.

Temir, M. (2015). Yaşayan tarih yetişkinlerimiz (Yayımlanmamış Yüksek Lisans Tezi). Gaziosmanpaşa Üniversitesi Eğitim Bilimleri Enstitüsü, Tokat.

The Salt Book Kitabının Kapak Fotoğrafi. Retrieved 14/05.2017 from https://www.amazon.com/Salt-Book-Lobstering-PuddingSnowshoes/dp/0385114230

Thompson, P. (1975). The Edwardians: The remaking of British society. London, Routledge.

Thompson, P. (1999). Geçmişin sesi. İstanbul: Tarih Vakfı Yurt Yayınları.

Tunçay, N. E. (1993). I. Sözlü tarih atölyesi (6-7 Haziran). İstanbul, Türkiye: Tarih Vakfi Yayınları.

Uluçay, Ç. (1958). Çevre incelemeleri tarih öğretimi. İstanbul: Öğretmenler Derneği Yayınları.

Yetman, N. R. (2001). An introduction to the WPA slave narratives. Born in Slavery: Slave Narratives from the Federal Writers' Project, 1936-1938. In The Library of Congress, American Memory Project.

Yıldırım, A. \& Şimsek, H. (2008). Nitel araştırma yöntemleri. Ankara: Seçkin Yayınevi.

YÖK Ulusal Tez Merkezi, (2017). https://tez.yok.gov.tr/UlusalTezMerkezi/ adresinden 21/10/2017 tarihinde alınmıştır.

Wigginton, E. (1972). The Foxfire Book: Hog dressing, log cabin building, mountain crafts and foods, planting by the signs, snake lore, hunting tales, faith healing, moonshining, and other affairs of plain living. Garden City, N.Y: Doubleday.

Wigginton, E. (1973). Foxfire 2: Ghost stories, spring wild plant foods, spinning and weaving, midwifing, burial customs, corn shuckin's, wagon making and more affair of plain living. Doubleday.

Wigginton, E. (1975). Foxfire 3: Animal care, banjos and dulcimers, hide tanning, summer and fall wild plant foods, butter churns, ginseng, and still more affairs of plain living. Garden City, N.Y: Anchor Press.

Wigginton, E. (1977). Fiddle making, spring houses, horse trading, sassafras tea, berry buckets, gardening and further affairs of plain living. Garden City, N.Y: Anchor Press/Doubleday. 
Wigginton, E. (1980). Foxfire 6: Eliot Wigginton. (1980). Shoemaking, 100 toys and games, gourd banjos and song bows, wooden locks, a water-powered sawmill, and other fascinating topics. Anchor. Garden City, N.Y: Anchor Press/Doubleday.

Wigginton, E., \& Bennett, M. (1984). Foxfire 8. Garden City, N.Y: Anchor Press/Doubleday.

Wigginton, E., \& et al. (1986). Foxfire 9. Anchor/Doubleday (pbk.).

Wood, P. (1977). The Salt book: lobstering, sea moss pudding, stone walls, rum running, maple syrup, snowshoes, and other Yankee doings. Anchor Books.

Wood, P. (1980). SALT 2: Boatbuilding, sailmaking, island people, river driving, bean hole beans, wooden paddles, and more Yankee doings. Garden City, N.Y: Anchor Press/Doubleday. 